\title{
Globalization and Investment in Human Capital
}

\author{
Daniel C. Hickman $\quad$ William W. Olney ${ }^{1}$
}

April 2010

\begin{abstract}
Workers are becoming increasingly concerned about the impact that globalization has on their domestic labor market. While existing research typically focuses on the effects on labor market outcomes such as wages and employment, we examine whether American workers respond to globalization by increasing their investment in human capital. Specifically, we measure the extent to which offshoring and immigration affect enrollment at institutions of higher education. The results indicate that both offshoring and immigration increase enrollment at community colleges, particularly among older students. We conclude that workers in the U.S. are responding to offshoring and immigration by acquiring the skills necessary to compete in a global economy.
\end{abstract}

Keywords: globalization, higher education, enrollment, offshoring, immigration

JEL Codes: F16, I2, J24

\footnotetext{
${ }^{1}$ Department of Economics, University of Colorado at Boulder, 256 UCB, Boulder, CO, 80309-256 (email: daniel.hickman@colorado.edu, william.olney@colorado.edu). We are grateful to Francisca Antman, Terra McKinnish, and Jeffrey Zax for helpful comments and suggestions.
} 


\section{Introduction}

Workers in the United States are increasingly competing in an integrated global labor market. This has led to considerable anxiety among workers and sparked substantial debate among politicians, the media, and the general public. This debate generally focuses on how globalization affects domestic wages and employment levels. However, relatively little is known about how globalization impacts investments in human capital. Are American workers responding to globalization by investing in the skills and knowledge that will allow them to succeed in an increasingly global economy? This paper uses a comprehensive dataset of U.S. higher education institutions to address this question.

Globalization, particularly in the forms of immigration and offshoring, increases the effective supply of low-skilled workers available to domestic firms. ${ }^{2}$ American firms have a larger pool of low-skilled immigrant workers as well as an increased ability to shift production facilities to low-skilled labor abundant countries. As a result, labor market competition caused by globalization has predominantly affected low-skilled native workers. A natural response is for native workers to acquire the skills necessary in order to avoid direct competition with foreign workers. The extent to which American workers have responded to this increased competition by returning to school is the focus of this paper.

In this analysis, we measure investments in human capital using enrollment at institutions of higher education. While we expect that, in general, workers are responding rationally by increasing their level of human capital, it is likely that globalization will have a heterogeneous effect on enrollments at different types of institutions. In particular, globalization likely impacts community colleges more than four-year institutions. The marginal worker affected by globalization is likely to find the short,

\footnotetext{
${ }^{2}$ Offshoring refers to the relocation of domestic jobs to foreign countries. This includes movements of jobs within a firm or to another foreign firm.
} 
technical training of community colleges appealing. Furthermore, relative to fouryear institutions, community colleges have a greater ability to adjust admissions in response to demand. We also examine whether the impact of offshoring and immigration on enrollment is sensitive to the location of the community college. We expect that offshoring, which largely affects urban areas, will have a particularly strong impact on enrollment at community colleges located in cities. Immigration, on the other hand, likely affects enrollments at both urban and rural institutions.

We next examine whether offshoring and immigration have heterogeneous effects on enrollments across different types of students. In particular, the impact of globalization on enrollment may differ depending on the age of the student. Older individuals who face immediate and direct competition due to immigration and offshoring likely return to school to acquire the skills that make them desirable in the labor market. Furthermore, immigration and offshoring may have a different effect on enrollments of students of different races.

This paper combines data on enrollment with data on immigration and offshoring to investigate how globalization affects investment in human capital. The data set used in the analysis is appealing because it incorporates enrollment data from the universe of higher education institutions in the U.S., it includes substantial variation in globalization across states, and the years included span exogenous shocks to both offshoring and immigration caused by China joining the World Trade Organization in 2001 and changes in immigration policy following 9/11.

The results confirm our expectations. Both offshoring and immigration lead to significant increases in enrollment at community colleges but have little impact at nondegree and bachelor institutions. We find evidence that the impact of offshoring on community college enrollment is particularly large for urban schools, while immigration increases enrollment at all types of community colleges. Furthermore, community college enrollment increases primarily through the impact offshoring and immigration 
have on older students (above 25 years old). We also find that the enrollments of White, Hispanic, and Asian students all increase by a similar amount in response to offshoring and immigration, while the enrollment of Black students remains relatively unchanged. These results indicate that American workers respond to increases in global competition by returning to school. Furthermore, these findings highlight the importance of community colleges in retraining native workers.

Numerous authors have studied the impact of globalization on domestic labor markets. For example, Feenstra and Hanson (1996, 1999) and Slaughter (2000) examine the effects that outsourcing and multinational activity have on the domestic wage distribution. Harrison and McMillan (2006) analyze changes in U.S. manufacturing employment resulting from changes in foreign affiliate wages. The impact of immigration on the domestic labor market has also been the focus of much research over the past few decades. Research by Card $(1990,2005)$ has generally shown a small effect on wages and employment of natives, while that of Borjas (2003) and Borjas et al. (1997) find a larger, more adverse, impact.

In general, research on the relationship between globalization and the domestic labor market focuses on the implications that global forces have on wages or employment. In this paper, we instead consider a more long-term implication of globalization by examining how offshoring and immigration affect the domestic worker's human capital investment decision. This particular aspect of the relationship remains relatively unexamined, yet plays a fundamental role in how the domestic labor market and economy ultimately adjust to increased globalization.

This paper also contributes to the literature examining how enrollments respond to local labor market conditions. Betts and McFarland (1995) and Kienzl et al. (2007), for example, attempt to estimate the impact that labor market conditions, such as unemployment, have on enrollment and attainment, respectively. However, it is possible that changes in enrollment may affect local labor market conditions. 
Specifically, increases in enrollment may reduce the unemployment rate or increase wages. We view offshoring and immigration as an exogenous shock that allows us to identify the causal effect of these global forces on local enrollment. ${ }^{3}$ Furthermore, local labor market indicators may not adequately account for increases in globalization if workers who are adversely affected by offshoring and immigration immediately return to school. In particular, offshoring and immigration may directly affect enrollment without leading to any changes in the unemployment rate.

The remainder of the paper is structured as follows. The anticipated impact of globalization on enrollment is outlined in Section 2. Section 3 presents the estimation strategy while Section 4 outlines the data used in this analysis. Section 5 discusses the estimated impact of offshoring and immigration on enrollments at different institutions and among different types of students. Section 6 presents additional robustness checks and Section 7 concludes.

\section{Conceptual Foundations}

Offshoring and immigration are both factors that effectively increase the labor supply available to domestic firms. As these factors have increased, domestic firms have access to additional foreign workers who can be employed both in the home and foreign country. Furthermore, offshoring and immigration have predominantly entailed relocating low-skilled tasks abroad and the immigration of low-skilled workers. ${ }^{4}$ These global forces are a labor supply shock that disproportionately affects low-skilled native workers.

There is a natural incentive for low-skilled native workers to respond to this increased competition by becoming more skilled. Native workers can avoid direct com-

\footnotetext{
${ }^{3}$ Black et al. (2005) use fluctuations in coal prices to examine the impact of an exogenous local shock on high school enrollment.

${ }^{4}$ Card (2005) shows that immigrants are less skilled than natives. Offshoring, to date, largely occurs in manufacturing industries (Blinder 2005, Amiti and Wei 2009, Olney 2009), and workers in these industries tend to be less skilled (US Census Bureau 2000).
} 
petition with foreign workers by acquiring the training and knowledge that move them up the skill distribution. Thus, increases in offshoring and immigration will lead to native workers returning to school. While this is an intuitively appealing result, there is little empirical evidence supporting this hypothesis.

While we expect college enrollment to increase in response to offshoring and immigration, the impact may be larger at particular types of institutions. The enrollment response to offshoring and immigration is likely to be strongest at community college institutions for a number of reasons. First, workers displaced due to globalization will find the short time frame, the emphasis on technical skills, and the relatively low cost appealing at community colleges. ${ }^{5}$ The marginal worker affected by offshoring and immigration is unlikely to commit the time and money required to attend a four-year institution. The opportunity costs of attending a four-year institution for displaced workers are high. Kane and Rouse (1999), for example, discuss the fact that the availability of night and weekend courses, the low costs of attendance, and the neighborhood convenience of community colleges are particularly appealing for many students.

Second, community colleges have the capacity to accommodate new students who are displaced due to globalization. While many four-year institutions are constrained by the available housing options, community colleges generally do not face these supply constraints, and also tend to adopt an open admissions policy (Kane and Rouse 1999). Community colleges have greater flexibility to add or subtract courses in response to demand.

Finally, unlike four-year institutions which attract students from various states, community colleges predominantly draw students from the local region. Thus, local labor market conditions may have a more substantial effect on community college enrollment. In contrast, local labor market conditions may affect enrollment at four-

\footnotetext{
${ }^{5}$ Jacobson et al. (2005) find that technical, vocation-oriented coursework at the community college level can have a large impact on the long-term earnings of displaced workers.
} 
year institutions in a number of different states due to the mobility of students. For all of these reasons, we expect the response of enrollment to offshoring and immigration to be more elastic at community colleges than at four-year institutions.

The impact of offshoring and immigration on community college enrollment may differ depending on the location of the institution. Since community colleges predominantly serve students from the local region, the implications for enrollment may differ based on the relative impact of offshoring and immigration in that area. As discussed previously, offshoring to date is most prevalent in the manufacturing industry and the majority of manufacturing jobs are located in urban areas. Thus, we expect offshoring to have a stronger impact on enrollment at community colleges that are located in cities. On the other hand, immigrants compete for manufacturing jobs in urban areas, but also for service and agricultural jobs in rural areas. Thus, we expect immigration to have a fairly homogeneous impact on enrollment at community colleges in all types of locations.

In addition to heterogeneous institution effects, offshoring and immigration likely differ in their impacts on various types of students. Specifically, we expect globalization to affect enrollment of older students relatively more than enrollment of younger students. In contrast to high school students, workers with established careers face acute labor market competition or perhaps displacement due to offshoring and immigration. In response to this global competition, these workers return to school for retraining. However, high school students are unlikely to respond to fluctuations in offshoring and immigration in such an immediate manner. High school students are less aware of increases in global competition and they may have difficulty calculating changes in the present discounted value of future income streams. Thus, we expect the impact of globalization on community college enrollment should be stronger among older cohorts of potential students.

Recent research has focused on the causes of educational attendance and attain- 
ment differences across various minority groups. ${ }^{6}$ Globalization may be another, relatively unexamined factor, affecting the educational investment decisions of particular racial groups. Therefore, we estimate how offshoring and immigration impact enrollments of students of different races. We are particularly interested in how enrollment responses of minority students compare to the enrollment responses of White students.

\section{Estimation Strategy}

We are interested in how globalization affects investment in human capital. Thus, we estimate the impact of immigration and offshoring on enrollment using the following equation:

$$
\text { Enroll }_{i, s, t}=\beta_{0}+\beta_{1} \operatorname{Im} g_{s, t-1}+\beta_{2} O f f_{s, t-1}+C_{i, t-1} \delta+L_{s, t-1} \theta+\lambda_{i}+\phi_{t}+\epsilon_{i, s, t}
$$

The dependent variable, Enroll $_{i, s, t}$, represents the total undergraduate enrollment at higher education institution $i$ located in state $s$ in year $t$. The independent variables of interest are our measures of globalization. We use two separate measures, immigration and offshoring, to quantify the degree to which the area surrounding an institution is affected by global forces. ${ }^{7}$ These variables are both measured at the state level. One practical reason for this is that we are limited in our ability to construct these variables, particularly our measure for offshoring, at a more disaggregated geographic level. However, it may well be that the state is the appropriate level for these variables even if more localized data were available. A large major-

\footnotetext{
${ }^{6}$ See Cameron and Heckman (2001) and Card and Krueger (2005).

${ }^{7}$ It is possible that immigration and offshoring may affect enrollments in neighboring states. However, this type of spillover effect would attenuate our results and thus work against the findings of this paper.
} 
ity of college students, particularly those on the margin of attending, enroll in their state of residence. Public institutions generally give preferential treatment to state residents in terms of acceptance, financial aid, and tuition. Thus, most individuals who would be induced to return to school would consider the choice set to be in-state institutions.

Given that our globalization variables are measured at the state level, it may seem natural to aggregate our dependent variable, Enroll, to the same level. We do not proceed in this manner so that we can include institution-specific information such as tuition and financial aid in our analysis. The $C$ matrix in the equation above represents these institutional level variables. We expect that an increase in tuition will reduce enrollment while an increase in financial aid will increase enrollment.

The standard errors in all regressions that follow are clustered at the state-year level. This corrects for any correlation in our standard errors that arises from the fact that our globalization variables are measured at the state-year level while our enrollment variables are at the institution-year level. Specifically, we are concerned that there may be some unobserved shock in state $s$ in year $t$ that may be affecting enrollment at all institutions in that state in a similar manner.

The $L$ matrix includes variables measured at the state level that capture labor market conditions other than globalization. In order to isolate and identify the effects of globalization, we include both state unemployment and median income to account for general economic conditions. A higher unemployment rate, for example, is an indication of poor labor market conditions and thus will lead to an increase in enrollment. The final terms in our equation, $\lambda$ and $\phi$, represent institution and year fixed effects respectively.

We also lag our independent variables to account for the fact that individual enrollment decisions generally take place during the first half of any given year. As a result, it is more likely that current enrollment is impacted by the changes in off- 
shoring and immigration from the previous year. In addition, when estimating this equation, both dependent and independent variables are transformed using the natural logarithm. This facilitates a more straightforward interpretation of the results. In particular, the log-log specification allows for more intuitive comparisons of the magnitude of estimated coefficients across heterogeneous groups.

One might be concerned about endogeneity. However, there are a number of important features of our estimation strategy that minimize this potential bias. First, offshoring and immigration are usually driven by factors, such as foreign economic conditions or policy changes, that are exogenous to local labor market conditions. Second, to the best of our knowledge, no studies have found that immigrantion or offshoring respond to enrollment in community colleges. However, it may be possible that immigration and offshoring respond to labor market conditions which might be correlated with community college enrollment. To account for this, we include the labor market characteristics such as the unemployment rate and the income level in our regressions, as well as the institution level characteristics of tuition and aid. ${ }^{8}$ Third, institution and year fixed effects are included in all regressions. Thus, any factors, such as access to credit, trends in community college enrollment, or differences in schools, that do not vary within years or institutions will be controlled for. Fourth, community college enrollment is measured at the institution level while the globalization variables are measured at the state level. It is difficult to argue that changes in enrollment at a community college could substantially affect statewide immigration and offshoring. Fifth, as discussed, all the independed variables are lagged one year. It is highly unlikely that the globalization variables from the previous year depends on current community college enrollment. Sixth, in the results that follow, we slice the data in a number of ways. It is difficult to argue, that a potential endogeneity bias only arises in the places in which we expect and do find significant results. Given all

\footnotetext{
${ }^{8}$ However, the results that follow are robust to the exclusion of these control variables.
} 
of these factors, we are confident that a causal impact of offshoring and immigration on community college enrollment has been identified. With that said, an additional check for endogeneity is pursued in Section 6.4.

\section{Data and Descriptive Statistics}

\subsection{Institution-Level Data}

The data on college enrollment, the dependent variable, come from the National Center for Education Statistics' Integrated Postsecondary Education Data System (IPEDS). This is a longitudinal dataset that provides information on the universe of higher education institutions in the United States. This includes not only universities, but also community colleges, vocational schools, and other types of institutions. For the purposes of this study we collected information on total undergraduate enrollment by institution. In addition, IPEDS also provides data on average in-state tuition and average financial aid received by institution and enrollment by various institution and student characteristics. The enrollment data span the years 2000-2007 and the 48 contiguous states. We restrict the sample to institutions that reported information for all years, leaving us with a total of 3,475 institutions.

\subsection{State-Level Data}

We quantify globalization at the state level using measures of offshoring and immigration. Immigration, the unemployment rate, and the median income are constructed using data from the $20001 \%$ sample of the U.S. Census, as well as the American Community Survey (ACS) from 2001 to 2006. ${ }^{9}$ Specifically, immigration is defined as the share of a state's working age (18 to 65) population that is foreign born. We

\footnotetext{
${ }^{9}$ Data were obtained from the IPUMS project at the University of Minnesota Population Center, http://usa.ipums.org/usa/.
} 
use the share to account for the fact that the same number of immigrants will have a much stronger effect in a state with a smaller population. Based on the work by Card and DiNardo(2000) and Card (2001), we are not concerned that outflows of native workers in response to immigration could affect our measure. Thus, changes in the share of foreign born residents will offer a good estimate of the relative size of immigrant inflows. ${ }^{10}$

Offshoring is defined as the share of employees at majority owned foreign affiliates of U.S. firms. Data on foreign affiliate employment by the industry of the foreign affiliate is provided by the U.S. Bureau of Economic Analysis (BEA). In order to create a state-level measure of offshoring, we follow the general method outlined in Olney (2009). We use the detailed BEA data on the number of foreign affiliate employees by year and 60 industries. These foreign employees are then assigned to a state using each state's share of national GDP in these detailed industries. Within each state, we then aggregate across these 60 industries to create the estimated level of foreign affiliate employment for each state. Finally, we calculate the share of foreign affiliate employment to total employment, including both domestic and foreign employees. To summarize, the offshoring variable is constructed in the following manner:

offshoring $_{s t}=\frac{\sum_{j}\left[\frac{G D P_{j s t}}{\sum_{s} G D P_{j s t}} * \text { Foreign_Affiliate_Empl }_{j t}\right]}{\text { Domestic_Empl }_{s t}+\sum_{j}\left[\frac{G D P_{j s t}}{\sum_{s} G D P_{j s t}} * \text { Foreign_Affiliate_Empl }_{j t}\right]} * 100$

\subsection{Descriptive Statistics}

\footnotetext{
${ }^{10}$ While the results that follow use this foreign-born share as the measure of immigration, the sign and significance of the coefficients of interest are robust to using the share of recent immigrants in a state instead. A recent immigrant is defined as a foreign born resident who moved into the state in the past year. While this alternate measure is less desirable due to a lack of data and the inability to calculate this measure for 2000 (since the 2000 Census does not include information about place of residency one year ago), the results are consistent.
} 
Table 1 displays the state average of total enrollment at institutions of higher education (2001-2007), as well as the state averages of the globalization variables (20002006). As discussed previously, immigration is measured as the share of the adult population that is foreign born and offshoring is measured as the share of foreign affiliate employees to total employment. Overall we see that both immigration and offshoring vary substantially across states. Figure 1 plots the state averages of immigration against offshoring. We see that globalization is affecting some states more than others and that some states are heavily impacted by only one factor. States such as California and New Jersey have relatively high shares of offshoring and immigration, while Montana, Maine, and North Dakota are the least impacted by these global forces. Michigan and Indiana have a high degree of offshoring only, while states such as Florida and Nevada have high immigrant shares only.

Table 2 presents an annual summary of enrollment and the two globalization measures. The globalization figures are averages weighted by state population. Both offshoring and immigration show a general increase in the extent of globalization, even within the relatively short period examined in this analysis. We also see that undergraduate enrollment is increasing over this period at a relatively rapid rate $(14.5$ percent from 2000 to 2007). Whether any of this increase can be attributed to the increases in globalization is the focus of this analysis.

Overall, these descriptive statistics indicate that the enrollment and globalization measures vary substantially both across states and over time. This provides insight into the dimensions and characteristics of the dataset used in this analysis. However, the fixed effects in the empirical estimation strategy will account for most of these differences. The analysis that follows exploits state specific variation over time to examine how globalization affects enrollment at specific institutions. Thus, it is the changes to globalization that occur within states that are most relevant to our analysis. 
Figure 2 presents the percentage changes from 2000 to 2006 for both measures of globalization. While our regression analysis will exploit changes from year to year, the long differences shown here are still useful for illustrating the general level of variation across states. The plot shows that states varied greatly in how their economies were impacted by globalization changes over the period. There are only a handful of states for which the immigration and offshoring measures declined, but there are a substantial number that experienced a decline in one measure and an increase in the other. The fact that the percentage changes in the two measures are not highly correlated $(\mathrm{r}=0.303)$ indicates that we are able to separately identify the impacts of the two main aspects of globalization. While globalization has had an increasing impact on the U.S. labor market, this figure is an indication that this impact has not been felt equally across states. We next present the results indicating the extent to which the differential impacts on states has affected investment in higher education.

\section{Results}

The basic empirical estimation strategy presented in Section 3 is used to test a variety of specifications. First, we examine the impact of globalization on enrollment by various institutional characteristics, including the highest degree offered and the location of the institution. Second, we investigate the impact of globalization on enrollments of different types of students, examining how enrollment responses differ by age and race.

\subsection{Results by Type of Institution}

We begin by examining the impact of globalization on all institutions that report total undergraduate enrollment, average tuition, and average financial aid. The results are presented in the first column of Table 3. As discussed in Section 3, both dependent 
and independent variables are in natural $\log$ form, so the coefficients are interpreted as elasticities. This means, for example, that a 10 percent increase in the foreign-born share of the population in a state leads to a 0.5 percent increase in enrollment at each higher education institution within that state. This result is significant at the 10 percent level. The offshoring coefficient is positive but insignificant. The coefficients on unemployment and tuition are significant and of the expected sign, while those for the financial aid and median income variables are insignificant. While we might expect these controls to significantly contribute to enrollment fluctuations, they may not be changing much over the period examined and thus would be captured by the fixed effects.

Columns 2-4 of Table 3 present the results of the same estimation strategy, disaggregated by type of institution. The breakdown is by highest degree offered by the institution. Column 2 displays the results for "Non-Degree" institutions, which are largely vocational, beauty, and technical schools. Compared to other types of institutions, there are fewer Non-Degree institutions that report enrollment figures. ${ }^{11}$ The unemployment rate is the only factor that significantly contributes to fluctuations in enrollment at these institutions. Globalization does not significantly impact enrollment at Non-Degree institutions.

Column 3 presents results for community colleges that offer an Associate's degree and nothing higher. Here we see that both globalization measures are highly significant. A 10 percent increase in the foreign-born share of the population in a state leads to a 1.2 percent increase in enrollment at community colleges in the state, while a 10 percent increase in the share of jobs offshored leads to a 2.5 percent increase in community college enrollment. Again in this specification, coefficients for unemployment and tuition are significant and of the expected sign.

\footnotetext{
${ }^{11}$ Institutions that receive any federal financial aid support, such as Pell Grants, are required by the Higher Education Act of 1965 to respond to IPEDS surveys. There are a large number of "Non-Degree" institutions that do not receive such support.
} 
The final column of Table 3 presents the results for institutions that offer at least a Bachelor's degree. These coefficients indicate that globalization does not have a significant impact on enrollment at these institutions. However, unemployment and tuition are significant and have the expected sign.

Overall, Table 3 indicates that there is an increase in investment in human capital at institutions located in states most affected by globalization. Specifically, we see enrollment at community colleges increase in these states. This is consistent with the intuition discussed in Section 2. Workers who are displaced likely find the short time frame and the emphasis on technical skills appealing at community colleges; community colleges are less affected by capacity constraints; and less mobile community college students are more likely to respond to local economic conditions. Thus, for the rest of the analysis, we focus on enrollment at the community college level.

\subsection{Results by Urbanization of Institution}

It is possible that enrollment responses will differ by the level of urbanization in the area around the institution. At the community college level, in particular, it is common for individuals to attend schools not only in-state but also within their local area of residence. If this is the case, then it is likely that an increase in offshoring within a state should disproportionately increase enrollment at community colleges located in more urban areas. Increases in immigration, on the other hand, may impact enrollment in both urban and rural settings.

Table 4 presents the estimation results examining enrollment response by the level of urbanization of the institution. ${ }^{12}$ The results indicate that immigration has a significant positive effect on community college enrollment in all types of locations. Offshoring, on the other hand, has a positive significant effect on enrollment in urban

\footnotetext{
${ }^{12}$ The urbanization measure is constructed by IPEDS using information on an institution's address. The "large city" category captures MSAs with populations over 250,000, "small city" includes MSAs with populations less than 250,000, and "towns \& rural" includes regions that are located outside MSAs.
} 
areas but no effect on enrollment in rural areas. These results confirm the notion that different areas of a state may be impacted by globalization to different degrees. Specifically, offshoring increases enrollment predominantly in urban areas while immigration increases enrollment in all settings. Next, we examine whether globalization has a heterogeneous effect on enrollments of different types of students.

\subsection{Results by Age}

This section examines whether the impact of globalization on enrollment differs across age groups. Table 5 presents the results of regressing enrollments of various age groups on the globalization and control variables. The specification allows for direct comparisons of the magnitude of coefficients across groups. In general, increases in globalization have a much stronger impact on community college enrollment among

older individuals. We see that for recent high school graduates (18 to 21-year-olds) an increase in immigration has a significant positive effect on enrollment, while offshoring has no effect. Offshoring has a significant positive impact on enrollment among those 25 to 39 years old. Immigration has a significant positive impact on enrollment for all age categories above 30 years old.

These results are consistent with our predictions. Older individuals respond to direct job displacement caused by globalization by returning to school. While younger individuals have a higher net present value of future earnings resulting from an Associates degree, these results indicate that high school graduates may have difficulty correctly calculating the gains from attending a community college. However, older individuals enroll to replace a set of skills they now know to be obsolete. Overall these results suggest that the increase in community college enrollment is driven by older individuals returning to school. 


\subsection{Results by Race}

This section focuses on the impact of globalization on the enrollments of different races. As discussed previously, recent research has examined the causes and consequences of differences in education across racial groups. We contribute to this literature by determining the extent to which different racial groups are responding to immigration and offshoring.

Table 6 presents the results of estimating the impact of globalization on community college enrollment by race. This analysis indicates that enrollments among White, Hispanic, and Asian individuals have all responded in a similar manner to globalization. The estimated coefficients on immigration and offshoring for these groups are positive, significant, and of similar magnitude. However, globalization does not have a significant impact on the community college enrollment of Black students. It is not clear from the analysis whether this is a result of Blacks being less affected by changes in globalization or being less responsive to these changes. While an interesting question, this falls outside of the scope of this particular study and will be explored further in future work.

\section{Sensitivity Analysis}

\subsection{Additional Measures of Globalization}

As a robustness check, we include two additional measures of globalization to our baseline estimation strategy. We are concerned that immigration and offshoring may be capturing variation in other types of globalization that are not adequately controlled for. Specifically, we include the share of inshored workers and the share of workers displaced due to import competition.

Data on inshoring, defined as the number of employees of majority owned U.S. 
affiliates of foreign firms, is obtained from the BEA. It is more straightforward to attribute foreign activity to the state in which it is conducted than it is to attribute U.S. activity abroad to the state of origin. Thus, the BEA provides a direct measure of inshoring, but only for the years 2002-2006. For 2000 and 2001, we attribute inshoring across states in the same manner as offshoring. We expect that increases in inshoring will increase job prospects and thus decrease enrollment.

Data on the number of workers displaced due to important competition is obtained from the Trade Adjustment Assistance (TAA) program. Workers who lose their jobs due to important competition may apply to the TAA program for training, job search and relocation funds, income support and other reemployment benefits. This is not a perfect proxy for imports, given the logistical process of applying and recieving assistance. However, this is the best available data on imports at the state level. ${ }^{13} \mathrm{We}$ expect that an increase in the number of displaced workers due to import competition will increase enrollment.

Regressions including the share of workers displaced due to import competition and the share of inshoring are reported in Table 7 . We see that the coefficients on immigration and offshoring have remained virtually identical to those reported in Table 3. Immigration and offshoring increase enrollment at community colleges and have no effect on enrollment at other institutions. Including inshoring and import competition does not change this result. Furthermore, import competition, measured using data from the TAA, does not significantly impact enrollment at any type of institution. While inshoring has no impact on enrollment at Non-Degree and Associate granting institutions, it does have a slight negative effect on enrollment at four year institutions. This coefficient is of the expected sign, and indicates that inshoring increases the job prospects of people who would otherwise consider enrolling at four

\footnotetext{
${ }^{13}$ Accoding to trade.gov, "no OM statistics are available for state-level imports. The collection of state import data presents enormous technical challenges, since it would require tracking foreign goods through the U.S. wholesale and retail distribution systems. Consequently, it is not currently possible, using OM data or any other U.S. trade data, to calculate state trade balances."
} 
year institutions. We conclude that the fundamental relationship between immigration, offshoring, and enrollment is robust to the inclusion of inshoring and import competition.

\subsection{Enrollment by Residency Status}

We have interpreted the positive coefficient on immigration as indicating that natives respond to influxes of immigrants by returning to school. An alternate interpretation is that the positive coefficient implies immigrants themselves are more likely to enroll at community colleges. However, if this were true we would expect immigration to affect the elasticities of some racial groups more than others. Specifically, since recent immigrants are predominantly Hispanic and Asian, immigration should have a relatively stronger effect on Hispanic and Asian enrollments. The fact that immigration affects White, Hispanic, and Asian enrollments in a similar manner, as seen in Table 6, refutes this theory. Instead these results suggest that enrollment among these different racial groups respond to immigration, rather than immigrants simply being more likely to enroll at community college.

As an additional robustness check, we gathered IPEDS data on the enrollment of non-resident aliens at community colleges. We then break total undergraduate enrollment at these institutions into two categories: non-resident alien and native. Table 8 presents the results of regressing these categories of enrollment separately on the standard set of independent variables. The results in column 3 indicate that there are not significant increases in enrollment among non-resident aliens in response to increases in immigration. In contrast, column 2 shows that the estimated impact of immigration on community college enrollment is driven by changes in the enrollment of native residents. This provides further evidence that the positive coefficient on immigration indicates a response in the human capital investment decision of native residents. 


\subsection{Low Skilled and High Skilled Immigration}

While immigrants to the United States are on average less skilled than natives (Card 2005), there is substantial variation in the skill level of these immigrants. The results so far show that community college enrollments increase in response to total immigration. However, it is possible to more carefully examine how community college enrollments respond to immigrants of different skill levels. ${ }^{14}$ Specifically, we expect low-skilled immigration to lead to an increase in enrollment as low-skilled native workers respond to this increase in competition by becoming more skilled. However, the impact of high skilled immigration is less clear since an inflow of skilled workers may put downward pressure on the returns to skill.

Table 9 reports the results where immigrantion is decomposed into a low-skilled immigrant share and a high-skilled immigrant share. A low-skilled immigrant is defined as a person with a high school degree or less and a high-skilled immigrant is defined as a person with more than a high school degree. Consistent with our previous results, we find that immigration only affects enrollments at community colleges. In addition, the results in Table 9 indicate that only low-skilled immigration increases community college enrollments while high-skilled immigration has no significant impact on enrollments. These results are consistent with the arguments presented in Section 2 and they provide addditional evidence that low-skilled natives are responding to an increase in competition from low-skilled immigrants by enrolling at community colleges.

\subsection{Endogeneity}

As discussed in Section 3, potential endogeneity concerns are minimized due to our estimation strategy which includes fixed effects, controls for labor market and institution characteristics, lagged indepedent variables, and different levels of aggregation.

\footnotetext{
${ }^{14}$ Unfortunately, a similar analysis for offshoring is impossible due to data limitations.
} 
Furthermore, we view offshoring and immigration as predominently being determined by factors that are exogenous to local labor market conditions. However, for the sake of argument, suppose that enrollments are affecting offshoring and immigration in that region in a manner that is not adequately contolled for with our labor market and insitution variables. Specifically, one might worry that an increase in enrollments may lead to a relatively limited supply of low-skilled workers in that region which in turn may encourage immigration and offshoring. This form of endogeneity would lead to a spurious positive bias in our coefficients.

As an additional robustness check, we estimate an alternate specification in which this spurious positive bias will be more severe. Specifically, we regess lagged enrollment on our contemporeneous independent variables. Given the time that it would take for enrollments to impact immigration and offshoring, the potential endogeneity bias would be larger in this specification than in our baseline estimation strategy in which we regress current enrollment on our lagged independent variables. However, in this alternate specification we are unlikely to estimate a causal impact of offshoring and immigration on enrollments. So significant positive coefficients on our globalization variables would indicate that this endogeneity bias is problematic.

Table 10 reports the results from this placebo regression. The results indicate that offshoring and immigration do not have a significant effect on enrollments at any type of institution. This is consistent with the arguments presented in this paper since it is unlikely that immigration and offshoring could effect enrollments last year. However, if one was worried about endogeneity, then this spurious bias in our globilazation variables would be even more severe in this specification. The fact that the coefficients on immigration and offshoring are insignicant suggests that there is little endogeniety bias and indicates that this paper has identified a causal impact of immigration and offshoring on enrollments. ${ }^{15}$

\footnotetext{
${ }^{15}$ As a further robustness check, we tried instumenting for immigrantion using historical immigrant enclaves (Card 2005, Lewis 2003). However, this instrument does not work as well at the state as it
} 


\section{Conclusion}

Workers in the United States have become increasingly concerned about the impact globalization has on their domestic labor market. Recent research has focused on the effect globalization has on labor market outcomes such as wages and unemployment. We examine a dimension that has not yet been explored, the impact that globalization has on human capital investment decisions.

Using data on college enrollment, immigration, and offshoring we analyze whether states that are more exposed to globalization have seen differential changes in enrollment. The results indicate that both immigration and offshoring have a positive effect on enrollment. These enrollment responses are stronger among particular types of institutions and among particular groups of students. Globalization leads to increases in enrollment at community colleges, but not at other types of institutions. The results also indicate that offshoring increases community college enrollment in urban locations, while immigration increases community college enrollment in all types of locations. Finally, we find that older individuals are more likely to be impacted by globalization, and that Blacks are less affected.

These results indicate that individuals are reacting in a rational way to globalization. As the low-skilled labor force faces increasing competition due to immigration and offshoring, native workers are responding by increasing their human capital. These results raise questions about the need for the government to fund the retraining programs of displaced workers, since American workers are returning to school on their own. One possible alternative policy is for increased governmental support for community colleges, as these institutions play a crucial role in retraining workers displaced due to globalization. The findings of this paper support plans such as the "American Graduation Initiative" announced in July 2009, which will invest more

does at the MSA level and the different levels of aggregation between the dependent and independent variables complicate this type of analysis. 
than $\$ 12$ billion in community colleges over the next ten years.

We are encouraged by the fact that American workers are responding to increases in offshoring and immigration by becoming better educated. This implies that the U.S. labor force is acquiring the skills and knowledge necessary to compete in a global economy. 


\section{References}

Amiti, Mary and Shang-Jin Wei. 2009. "Service Offshoring and Productivity: Evidence from the US." World Economy, 32(2): 203-20.

Bartel, Ann P. 1989. "Where Do the New U.S. Immigrants Live?" Journal of Labor Economics, 7(4): 371-91.

Betts, Julian R. and Laurel L. McFarland. 1995. "Safe Port in a Storm: The Impact of Labor Market Conditions on Community College Enrollments." Journal of Human Resources, 30(4): 741-65.

Black, Dan A., Terra G. McKinnish, and Seth G. Sanders. 2005. "Tight Labor Markets and the Demand for Education: Evidence from the Coal Boom and Bust." Industrial and Labor Relations Review, 59(1): 3-16.

Blinder, Alan S. 2005. "Fear of Offshoring." Working Paper No. 119, Center for Economic Policy Studies.

Borjas, George J. 2003. "The Labor Demand Curve is Downward Sloping: Reexamining the Impacts of Immigration on the Labor Market." Quarterly Journal of Economics, 118(4): 1335-74.

Borjas, George J., Richard B. Freeman, and Lawrence F. Katz. 1997. "How Much Do Immigration and Trade Affect Labor Market Outcomes?" Brookings Papers on Economic Activity, 1997(1): 1-90.

Cameron, Stephen V., and James J. Heckman. 2001. "The Dynamics of Educational Attainment for Black, White, and Hispanic Males." Journal of Political Economy, 109(3): 455-99.

Card, David. 1990. "The Impact of the Mariel Boatlift on the Miami Labor Market." Industrial and Labor Relations Review, 43(2): 245-57. 
Card, David. 2001. "Immigrant Inflows, Native Outflows, and the Local Market Impacts of Higher Immigration." Journal of Labor Economics, 19(1): 22-64.

Card, David. 2005. "Is the New Immigration Really so Bad?" The Economic Journal, 115(507): F300-23.

Card, David and John DiNardo. 2000. "Do Immigrant Inflows Lead to Native Outflows?" American Economic Review, 90(2): 360-7.

Card, David and Alan B. Krueger. 2005. "Would the Elimination of Affirmative Action Affect Highly Qualified Minority Applicants? Evidence from California and Texas." Industrial and Labor Relations Review, 58(3): 416-34.

Cragg, Michael and Matthew Kahn. 1997. "New Estimates of Climate Demand: Evidence from Location Choice." Journal of Urban Economics, 42(2): 261-84.

Feenstra, Robert C. and Gordon H. Hanson. 1996. "Globalization, Outsourcing, and Wage Inequality." A.E.R. Papers and Proceedings, 86 (2): 240-45.

Feenstra, Robert C. and Gordon H. Hanson. 1999. "The Impact of Outsourcing and High-Technology Capital on Wages: Estimates for the United States, 1979-1990." The Quarterly Journal of Economics, 114(3): 907-40.

Hanson, Gordon H., Kenneth F. Sheve, Matthew J. Slaughter, and Antonio Spilimbergo. 2002. "Immigration and the U.S. Economy: Labor-Market Impacts, Illegal Entry, and Policy Choices." In Immigration Policy and the Welfare System, ed. Tito Boeri, Gordon Hanson, and Barry McCormick, 169-279. Oxford University Press.

Harrison, Ann E. and Margaret S. McMillan. 2006. "Outsourcing Jobs? Multinationals and US Employment." Working Paper No. 12372, National Bureau of Economic Research. 
Jacobson, Louis, Robert LaLonde, and Daniel G. Sullivan. 2005. "Estimating the Returns to Community College Schooling for Displaced Workers." Journal of Econometrics, 125(1): 271-304.

Kane, Thomas J. and Cecilia B. Rouse. 1999. "The Community College: Educating Students at the Margin between College and Work." Journal of Economic Perspectives, 13(1): 63-84.

Kienzl, Gregory S., Mariana Alfonso, and Tatiana Melguizo. 2007. "The Effect of Local Labor Market Condition in the 1990s on the Likelihood of Community College Students' Persistence and Attainment." Research in Higher Education, 48(7): 75173.

Olney, William W. 2009. "Offshoring, Immigration, and the Native Wage Distribution." Working Paper No. 1365288, Social Science Research Network (SSRN).

Ruggles, Steven, Matthew Sobek, Trent Alexander, Catherine A. Fitch, Ronald Goeken, Patricia Kelly Hall, Miriam King, and Chad Ronnander. 2009. Integrated Public Use Microdata Series: Version 4.0. Minneapolis, MN: Minnesota Population Center.

Slaughter, Matthew J. 2000. "Production Transfer within Multinational Enterprises and American Wages." Journal of International Economics, 50(2): 449-72.

U.S. Census Bureau, Population Division. 2000. "Table 7: Educational Attainment of Employed Civilians 18 to 64 Years, by Industry." Available online: http://www.census.gov/population/socdemo/education/p20-536/tab07.pdf 
TABLE 1

State Averages

\begin{tabular}{|c|c|c|c|c|}
\hline State & Total Enrollment & Enrollment Share & Immigration & Offshoring \\
\hline Alabama & 214,473 & 7.5 & 3.7 & 4.6 \\
\hline Arizona & 417,485 & 11.6 & 17.1 & 4.5 \\
\hline Arkansas & 126,742 & 7.4 & 4.5 & 4.6 \\
\hline California & $2,195,971$ & 9.7 & 33.2 & 5.2 \\
\hline Colorado & 253,005 & 8.3 & 11.0 & 4.3 \\
\hline Connecticut & 147,484 & 6.7 & 16.2 & 5.5 \\
\hline Delaware & 42,503 & 8.1 & 9.3 & 5.2 \\
\hline Florida & 776,948 & 7.3 & 22.7 & 3.5 \\
\hline Georgia & 366,512 & 6.4 & 10.3 & 5.0 \\
\hline Idaho & 68,001 & 7.9 & 6.8 & 3.9 \\
\hline Illinois & 665,780 & 8.3 & 14.6 & 5.2 \\
\hline Indiana & 309,056 & 7.9 & 4.6 & 7.2 \\
\hline Iowa & 197,449 & 10.8 & 3.8 & 5.1 \\
\hline Kansas & 170,285 & 10.0 & 5.3 & 3.9 \\
\hline Kentucky & 197,366 & 7.4 & 3.0 & 5.8 \\
\hline Louisiana & 203,212 & 7.3 & 4.1 & 4.7 \\
\hline Maine & 57,347 & 6.9 & 4.2 & 3.0 \\
\hline Maryland & 259,086 & 7.3 & 13.3 & 3.8 \\
\hline Massachusetts & 338,077 & 8.1 & 16.3 & 5.1 \\
\hline Michigan & 531,266 & 8.4 & 6.6 & 7.9 \\
\hline Minnesota & 279,585 & 8.7 & 6.2 & 4.5 \\
\hline Mississippi & 132,671 & 7.4 & 2.2 & 3.7 \\
\hline Missouri & 293,859 & 8.1 & 4.2 & 4.7 \\
\hline Montana & 42,536 & 7.3 & 2.7 & 2.2 \\
\hline Nebraska & 103,551 & 9.6 & 5.5 & 4.0 \\
\hline Nevada & 92,434 & 6.2 & 20.9 & 3.5 \\
\hline New Hampshire & 57,476 & 6.9 & 6.2 & 4.5 \\
\hline New Jersey & 331,073 & 6.1 & 23.3 & 5.5 \\
\hline New Mexico & 111,509 & 9.5 & 10.8 & 4.3 \\
\hline New York & 952,513 & 7.7 & 23.9 & 4.9 \\
\hline North Carolina & 415,114 & 7.5 & 8.0 & 5.9 \\
\hline North Dakota & 43,272 & 10.8 & 2.9 & 3.2 \\
\hline Ohio & 537,610 & 7.5 & 4.3 & 5.9 \\
\hline Oklahoma & 191,717 & 8.7 & 5.8 & 4.0 \\
\hline Oregon & 176,011 & 7.6 & 10.1 & 5.2 \\
\hline Pennsylvania & 579,629 & 7.5 & 6.0 & 4.8 \\
\hline Rhode Island & 71,316 & 10.5 & 14.3 & 4.0 \\
\hline South Carolina & 185,973 & 6.9 & 5.4 & 4.9 \\
\hline South Dakota & 41,868 & 8.9 & 2.7 & 3.6 \\
\hline Tennessee & 247,650 & 6.5 & 4.5 & 5.5 \\
\hline Texas & $1,070,523$ & 7.6 & 18.4 & 5.3 \\
\hline Utah & 173,689 & 11.7 & 8.7 & 3.6 \\
\hline Vermont & 33,592 & 8.3 & 4.8 & 3.8 \\
\hline Virginia & 366,478 & 7.5 & 12.1 & 4.7 \\
\hline Washington & 314,454 & 7.8 & 13.6 & 4.0 \\
\hline West Virginia & 80,989 & 7.0 & 1.7 & 3.7 \\
\hline Wisconsin & 293,426 & 8.4 & 4.2 & 5.2 \\
\hline Wyoming & 30,245 & 9.3 & 3.4 & 4.2 \\
\hline
\end{tabular}


FIGURE 1

Offshoring and Immigration by State (2000-2006 Average)

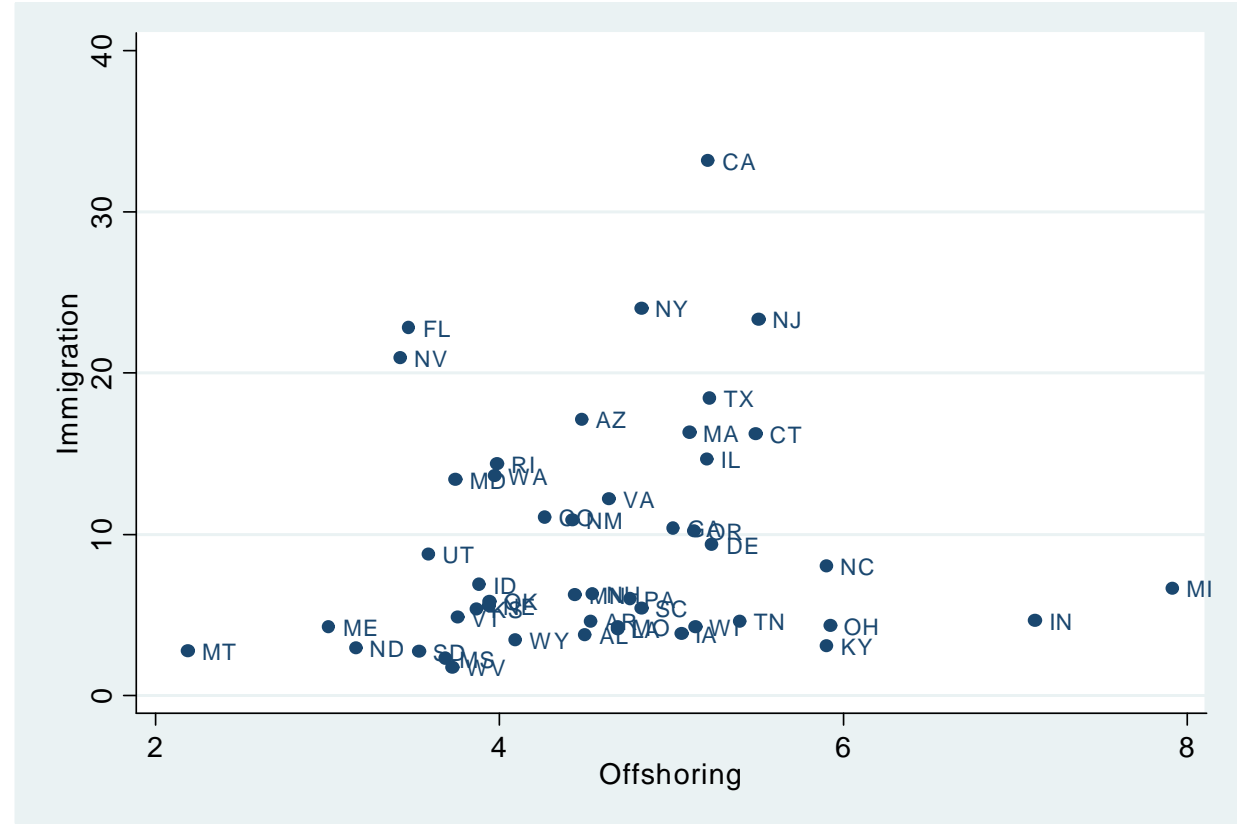

This figure plots the state average of the share of the population that is foreign born against the state average of the share of foreign affiliate employees.

TABLE 2

Year Averages

\begin{tabular}{ccccc}
\hline Year & Enrollment & Enrollment Share & Immigration & Offshoring \\
\hline $\mathbf{2 0 0 0}$ & $13,223,412$ & 7.5 & 14.4 & 4.9 \\
$\mathbf{2 0 0 1}$ & $13,823,976$ & 7.8 & 13.9 & 4.9 \\
$\mathbf{2 0 0 2}$ & $14,415,372$ & 8.0 & 14.2 & 5.0 \\
$\mathbf{2 0 0 3}$ & $14,610,108$ & 8.0 & 14.6 & 5.0 \\
$\mathbf{2 0 0 4}$ & $14,889,081$ & 8.1 & 14.4 & 5.0 \\
$\mathbf{2 0 0 5}$ & $15,005,920$ & 8.1 & 14.7 & 5.1 \\
$\mathbf{2 0 0 6}$ & $15,204,562$ & 8.1 & 15.0 & 5.2 \\
$\mathbf{2 0 0 7}$ & $15,572,636$ & 8.2 & - & - \\
\hline
\end{tabular}

This table includes the total annual enrollment and the enrollment to adult population ratio. Annual averages of the share of the population that is foreign born and the share of foreign affiliate employees are weighted by state population. 


\section{FIGURE 2}

Percentage Changes in Offshoring and Immigration by State (2000-2006)

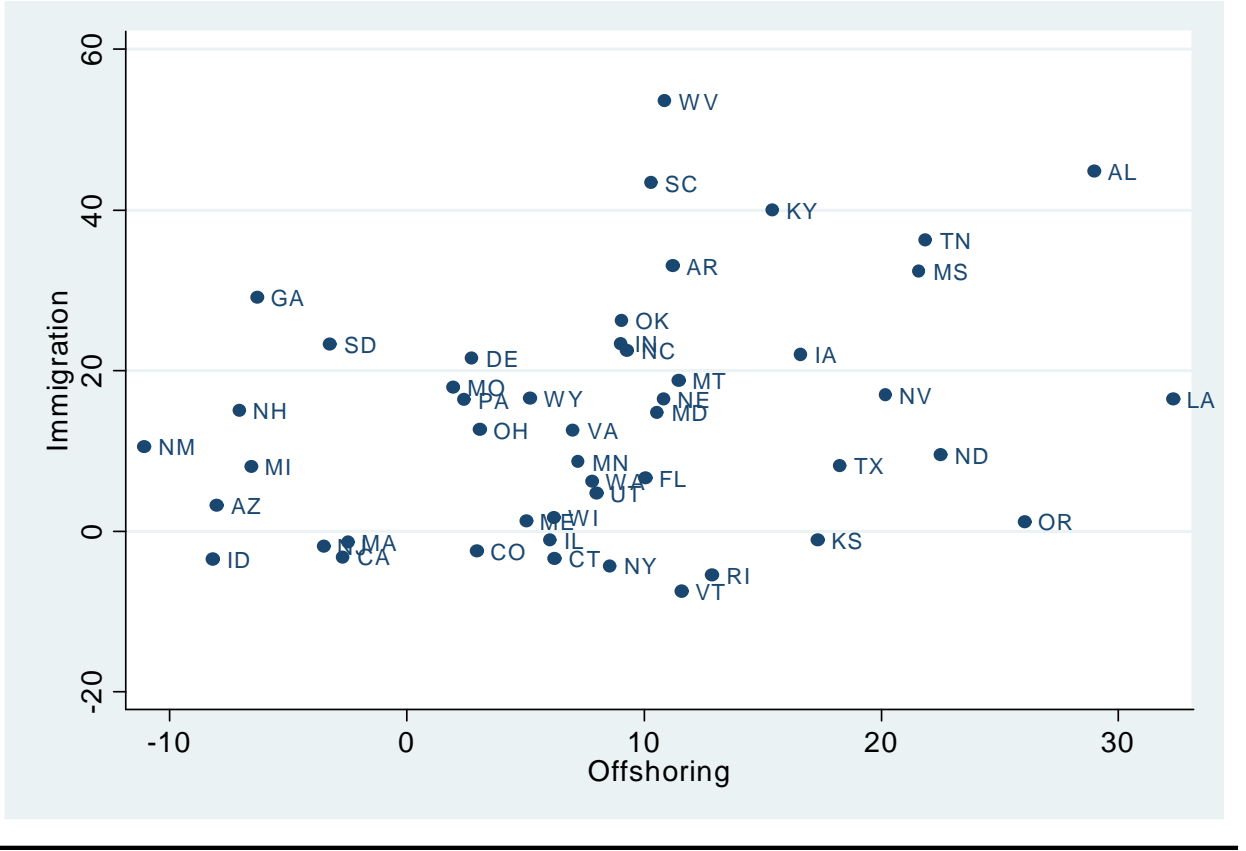

This figute plots the percent change in the share of the population that is foreign born against the percent change in the share of foreign affiliate employees. 


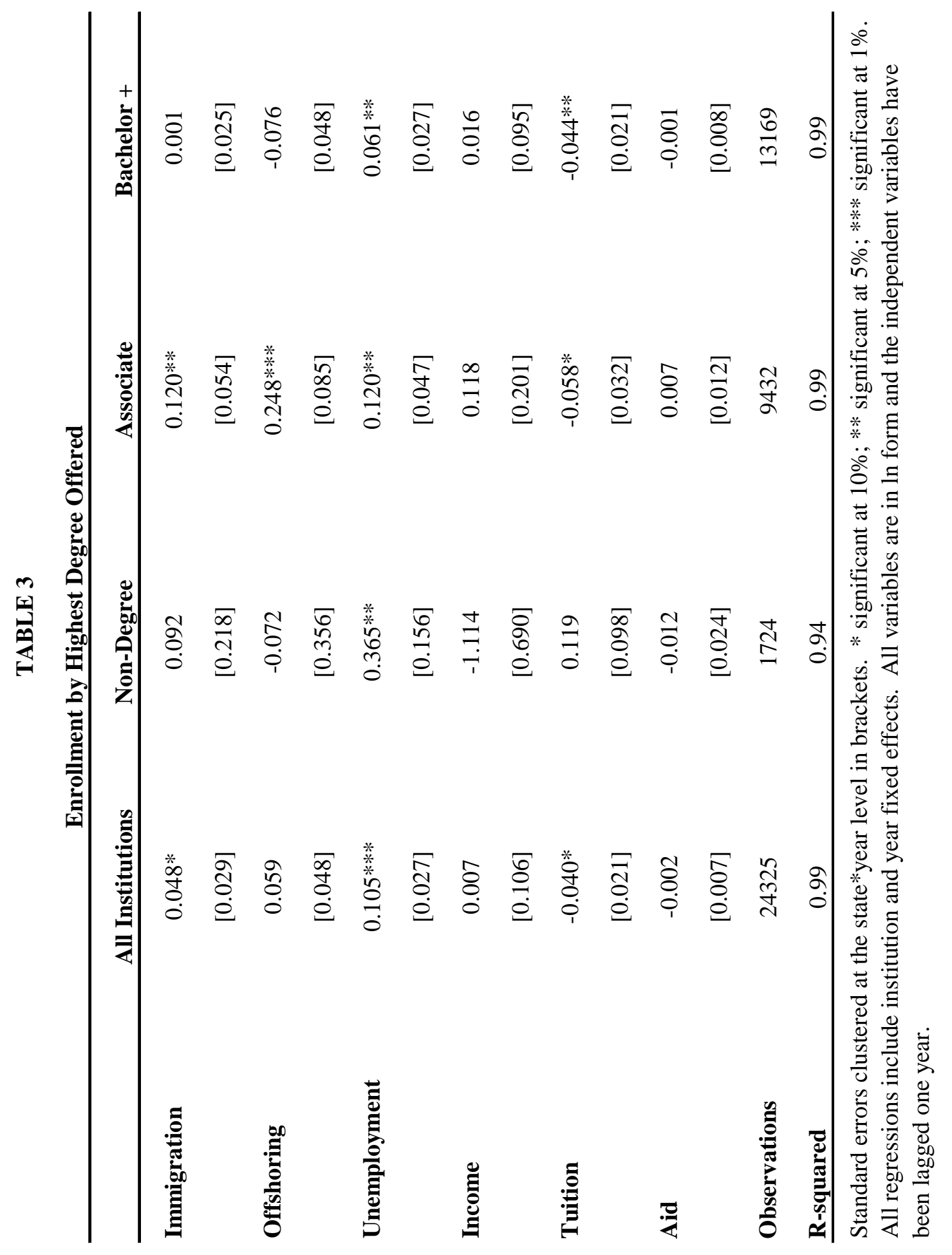




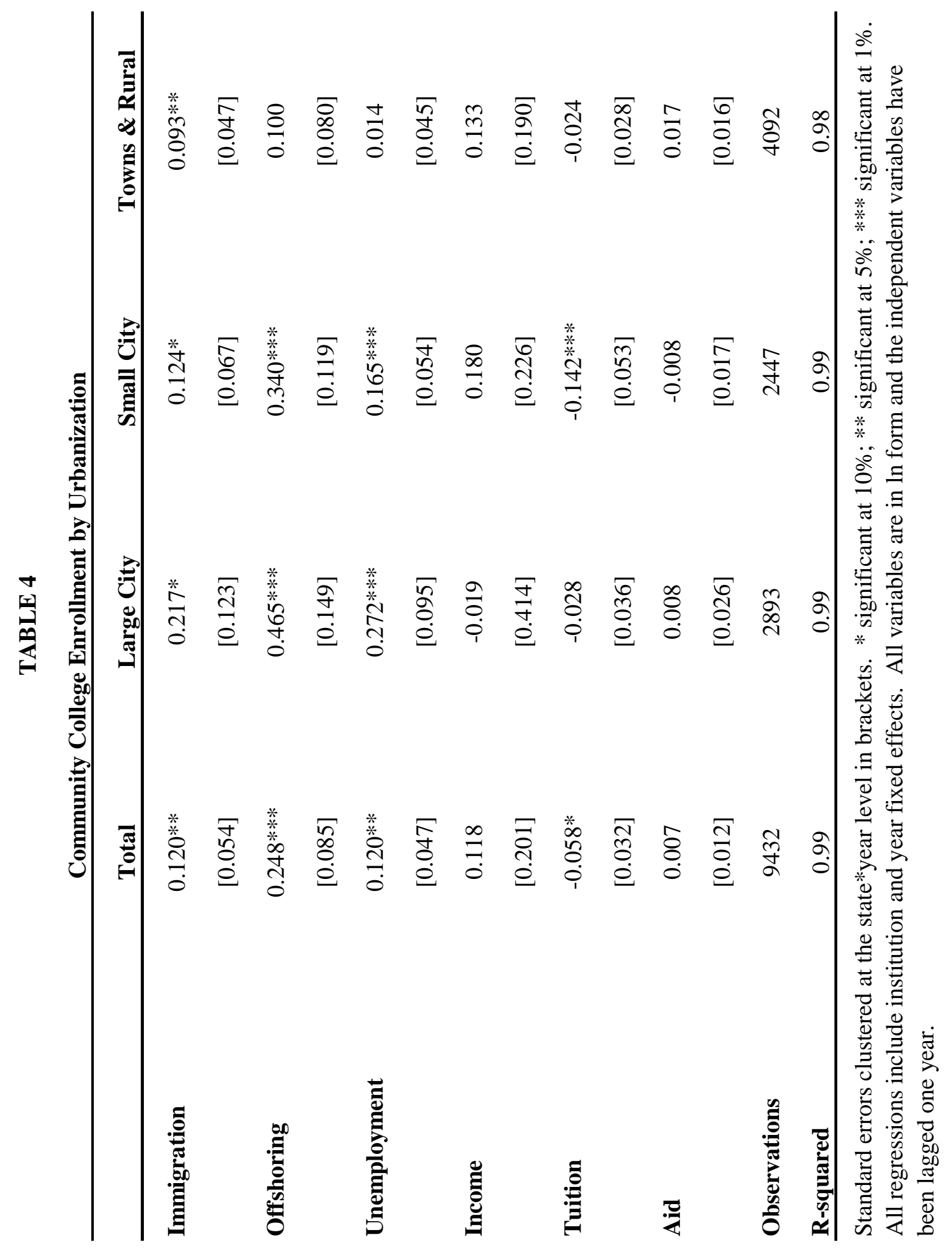




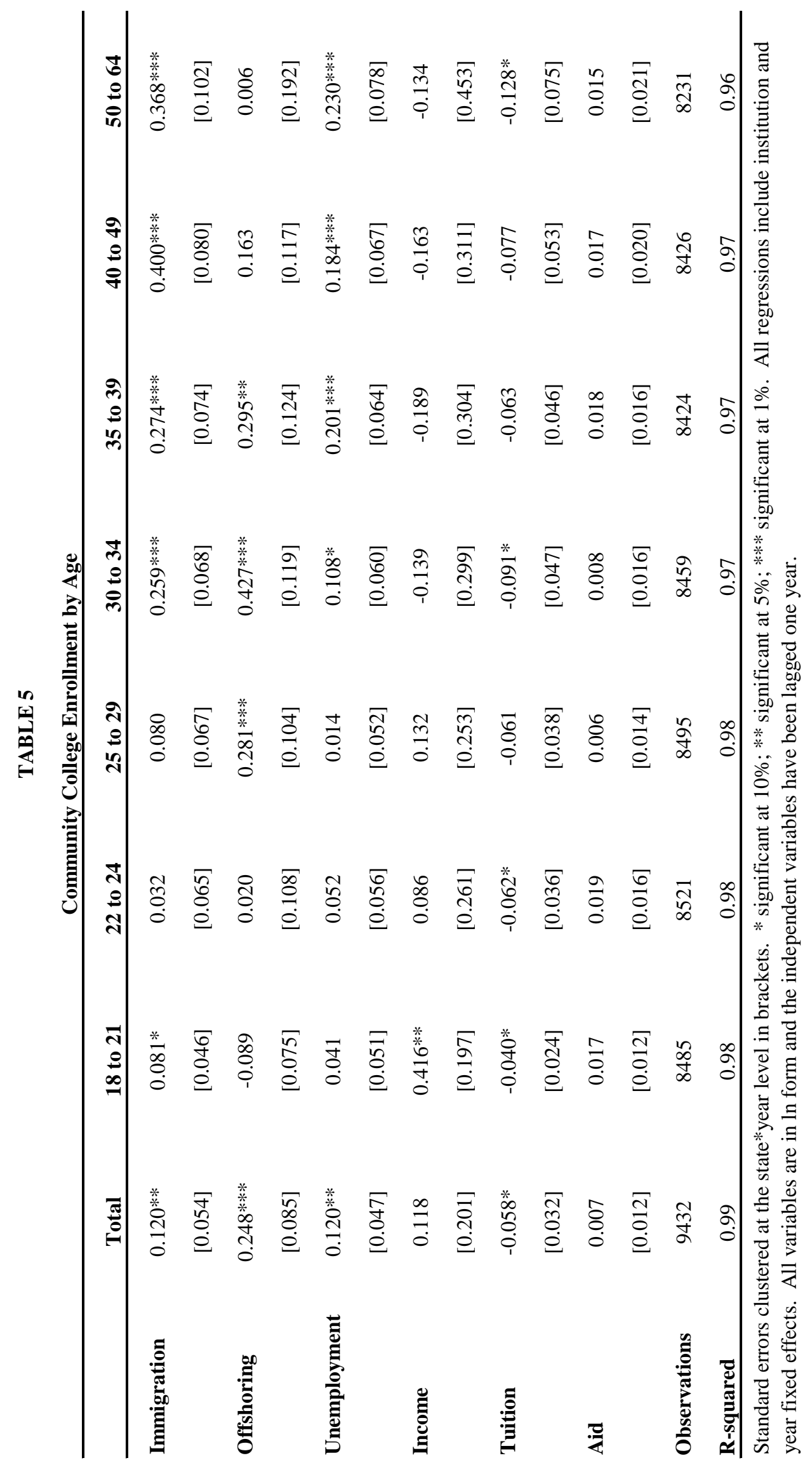




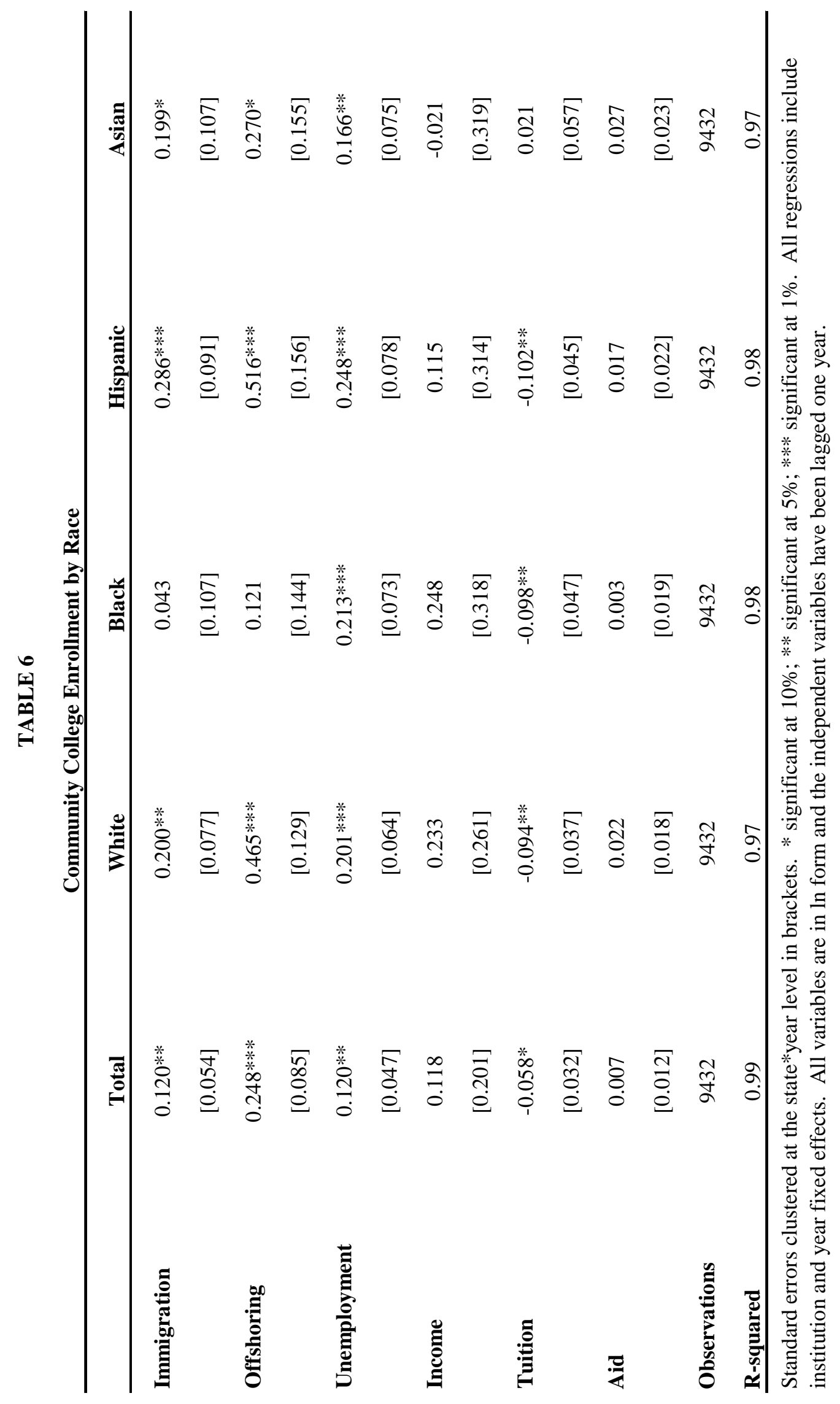




\section{TABLE 7}

Enrollment by Highest Degree Offered (Including Import Competition and Inshoring)

\begin{tabular}{|c|c|c|c|}
\hline & Non-Degree & Associate & Bachelor + \\
\hline \multirow[t]{2}{*}{ Immigration } & 0.139 & $0.116^{* *}$ & 0.002 \\
\hline & {$[0.226]$} & {$[0.054]$} & {$[0.024]$} \\
\hline \multirow[t]{2}{*}{ Offshoring } & -0.101 & $0.242 * * *$ & -0.075 \\
\hline & {$[0.356]$} & [0.085] & {$[0.046]$} \\
\hline \multirow[t]{2}{*}{ Import Competition } & -0.042 & -0.003 & 0.003 \\
\hline & {$[0.032]$} & {$[0.005]$} & {$[0.003]$} \\
\hline \multirow[t]{2}{*}{ Inshoring } & 0.199 & 0.037 & $-0.046 * * *$ \\
\hline & [0.161] & {$[0.036]$} & [0.016] \\
\hline \multirow[t]{2}{*}{ Unemployment } & $0.406 * *$ & $0.117 * *$ & $0.065 * *$ \\
\hline & [0.169] & {$[0.047]$} & {$[0.026]$} \\
\hline \multirow[t]{2}{*}{ Income } & $-1.455^{* *}$ & 0.110 & 0.041 \\
\hline & {$[0.655]$} & {$[0.202]$} & {$[0.092]$} \\
\hline \multirow[t]{2}{*}{ Tuition } & 0.120 & $-0.057 *$ & $-0.045 * *$ \\
\hline & [0.099] & {$[0.031]$} & {$[0.021]$} \\
\hline \multirow[t]{2}{*}{ Aid } & -0.009 & 0.006 & -0.001 \\
\hline & {$[0.025]$} & [0.012] & {$[0.008]$} \\
\hline Observations & 1724 & 9432 & 13169 \\
\hline R-squared & 0.94 & 0.99 & 0.99 \\
\hline
\end{tabular}

Standard errors clustered at the state*year level in brackets. * significant at $10 \% ; * *$ significant at $5 \%$; *** significant at $1 \%$. All regressions include institution and year fixed effects. All variables are in $\ln$ form and the independent variables have been lagged one year. 
TABLE 8

Community College Enrollment by Residence Status

\begin{tabular}{lccc}
\hline & Total & Native & Non-Resident Alien \\
\hline Immigration & $0.120^{* *}$ & $0.116^{* *}$ & 0.082 \\
& {$[0.054]$} & {$[0.053]$} & {$[0.130]$} \\
Offshoring & $0.248^{* * *}$ & $0.254^{* * *}$ & -0.330 \\
& {$[0.085]$} & {$[0.084]$} & {$[0.225]$} \\
Unemployment & $0.120^{* *}$ & $0.124^{* * *}$ & -0.132 \\
Income & {$[0.047]$} & {$[0.047]$} & {$[0.106]$} \\
& 0.118 & 0.126 & 0.566 \\
Tuition & {$[0.201]$} & {$[0.200]$} & {$[0.551]$} \\
& $-0.058^{*}$ & $-0.058^{*}$ & $-0.084 *$ \\
Aid & {$[0.032]$} & {$[0.032]$} & {$[0.049]$} \\
Observations & 0.007 & 0.007 & 0.002 \\
R-squared & {$[0.012]$} & {$[0.012]$} & {$[0.025]$} \\
Standard & 9432 & 9432 & 9432 \\
& 0.99 & 0.99 & 0.92 \\
\hline
\end{tabular}

Standard errors clustered at the state*year level in brackets. * significant at $10 \%$; ** significant at $5 \%$; *** significant at $1 \%$. All regressions include institution and year fixed effects. All variables are in $\ln$ form and the independent variables have been lagged one year. 
TABLE 9

Enrollment by Highest Degree Offered with Low and High Skilled Immigration

\begin{tabular}{lccc}
\hline & Non-Degree & Associate & Bachelor + \\
\hline L_Skill Immigration & 0.109 & $0.117 * * *$ & -0.005 \\
H_Skill Immigration & {$[0.198]$} & {$[0.039]$} & {$[0.021]$} \\
Offshoring & -0.062 & -0.011 & 0.019 \\
& {$[0.187]$} & {$[0.042]$} & {$[0.027]$} \\
Unemployment & -0.086 & $0.239 * * *$ & $-0.079 *$ \\
& {$[0.356]$} & {$[0.084]$} & {$[0.047]$} \\
Income & $0.360 * *$ & $0.124 * * *$ & $0.061 * *$ \\
& {$[0.156]$} & {$[0.047]$} & {$[0.027]$} \\
Tuition & -1.047 & 0.138 & -0.002 \\
& {$[0.710]$} & {$[0.200]$} & {$[0.096]$} \\
Aid & 0.120 & $-0.061 *$ & $-0.044 * *$ \\
Observations & {$[0.098]$} & {$[0.031]$} & {$[0.021]$} \\
\hline Stsquared & -0.011 & 0.007 & -0.001 \\
& {$[0.024]$} & {$[0.012]$} & {$[0.008]$} \\
& 1724 & 9432 & 13169 \\
& 0.94 & 0.99 & 0.99 \\
\hline
\end{tabular}

Standard errors clustered at the state*year level in brackets. * significant at 10\%; ** significant at 5\%; *** significant at $1 \%$. All regressions include institution and year fixed effects. All variables are in $\ln$ form and the independent variables have been lagged one year. 
TABLE 10

Lagged Enrollment by Highest Degree Offered

\begin{tabular}{|c|c|c|c|}
\hline & Non-Degree & Associate & Bachelor + \\
\hline \multirow[t]{2}{*}{ Immigration } & -0.420 & 0.100 & 0.022 \\
\hline & [0.262] & [0.063] & [0.039] \\
\hline \multirow[t]{2}{*}{ Offshoring } & -0.547 & 0.118 & -0.106 \\
\hline & [0.380] & [0.111] & [0.077] \\
\hline \multirow[t]{2}{*}{ Unemployment } & 0.094 & $0.142 * *$ & -0.044 \\
\hline & {$[0.150]$} & [0.066] & [0.043] \\
\hline \multirow[t]{2}{*}{ Income } & -0.280 & -0.094 & 0.100 \\
\hline & [0.677] & {$[0.250]$} & [0.159] \\
\hline \multirow[t]{2}{*}{ Tuition } & -0.053 & $-0.140 * * *$ & $-0.078 * * *$ \\
\hline & [0.081] & {$[0.030]$} & [0.028] \\
\hline \multirow[t]{2}{*}{ Aid } & -0.010 & 0.023 & 0.011 \\
\hline & [0.038] & [0.019] & [0.011] \\
\hline Observations & 1586 & 8291 & 11508 \\
\hline R-squared & 0.92 & 0.98 & 0.99 \\
\hline
\end{tabular}


TABLE 11

Community College Enrollment Excluding Control Variables

\begin{tabular}{|c|c|c|c|c|}
\hline \multirow[t]{2}{*}{ Immigration } & $0.120 * *$ & $0.125 * *$ & $0.138 * *$ & $0.139 * *$ \\
\hline & {$[0.054]$} & {$[0.055]$} & {$[0.055]$} & [0.056] \\
\hline \multirow[t]{2}{*}{ Offshoring } & $0.248 * * *$ & $0.237 * * *$ & $0.214 * *$ & $0.203^{* *}$ \\
\hline & [0.085] & {$[0.088]$} & {$[0.086]$} & [0.090] \\
\hline \multirow[t]{2}{*}{ Unemployment } & $0.120 * *$ & $0.124 * *$ & & \\
\hline & [0.047] & {$[0.048]$} & & \\
\hline \multirow[t]{2}{*}{ Income } & 0.118 & 0.068 & & \\
\hline & {$[0.201]$} & {$[0.201]$} & & \\
\hline \multirow[t]{2}{*}{ Tuition } & $-0.058^{*}$ & & $-0.059 *$ & \\
\hline & {$[0.032]$} & & {$[0.031]$} & \\
\hline \multirow[t]{2}{*}{ Aid } & 0.007 & & 0.008 & \\
\hline & {$[0.012]$} & & {$[0.013]$} & \\
\hline Observations & 9432 & 9432 & 9432 & 9432 \\
\hline R-squared & 0.99 & 0.99 & 0.99 & 0.99 \\
\hline
\end{tabular}

